\title{
Association between Aldosterone Synthase CYP11B2 Polymorphism and Essential Hypertension in Chinese: A Meta-Analysis
}

\author{
Xiaoshu Cheng ${ }^{\mathrm{a}}$ Gaosi Xub,c \\ Departments of ${ }^{\mathrm{a}}$ Cardiology and ${ }^{\mathrm{b}}$ Nephrology, Second Affiliated Hospital, Nanchang University, Nanchang, and \\ 'Department of Immunology, Shangrao Branch of Jiangxi Medical College, Shangrao, PR China
}

\section{Key Words}

Aldosterone · Polymorphism • Hypertension •

Meta-analysis

\begin{abstract}
A thymidine-to-cytosine substitution in the -344 promoter region of the aldosterone synthase gene (CYP11B2) has been associated with essential hypertension in some but not all studies conducted in Chinese. We performed a meta-analysis to evaluate the association of the $-344 \mathrm{C} / \mathrm{T}$ polymorphism with essential hypertension in Chinese. A total of 7,472 individuals $(4,259$ unselected hypertensive patients and 3,213 normotensive controls) from 9 case-control studies were included in the present investigation. Significant associations between the risk of hypertension and the CC genotype and $\mathrm{C}$ allele frequencies were found in a total of 19 studies. Our findings support the notion that the CYP11B2 -344C/T polymorphism is associated with essential hypertension. In addition, $C$ allele frequency was found to be lower in southern Chinese controls than in their northern counterparts, and the higher TT genotype homozygous frequency in the southern Chinese supports the hypothesis that the northern Chinese are of southern origin.
\end{abstract}

\section{Introduction}

Aldosterone synthase CYP11B2 is a key enzyme in the biosynthesis of aldosterone, a $-344 \mathrm{C} / \mathrm{T}$ polymorphism in the promoter region of the CYP11B2 gene, which has been reported to be in association with hypertension. Many researchers have studied the relationship between $-344 \mathrm{C} / \mathrm{T}$ polymorphism and hypertension. However, there were apparent discrepancies among the results of these association studies [1-12].

The position of -344 of the CYP11B2 gene is located in the promoter region of chromosome 8q24.3. The potential influence of the $-344 \mathrm{C} / \mathrm{T}$ variant on the promoter activity of CYP11B2 was analyzed in several studies. White et al. [13] found that the $-344 \mathrm{C}$ allele of the CYP11B2 promoter binds the steroidogenic transcription factor (SF-1) 4 times more than the $-344 \mathrm{~T}$ allele in gelshift assays. The $-344 \mathrm{C} / \mathrm{T}$ polymorphism at the SF-1 site is thought to alter the sensitivity of CYP11B2 to angiotensin II [8]. The relationship between the SF-1 genotype, blood pressure and the aldosterone-to-renin ratio was analyzed in several studies $[1,14]$.

The authors contributed equally to this work.

\section{KARGER \\ Fax +41613061234 E-Mail karger@karger.ch} www.karger.com

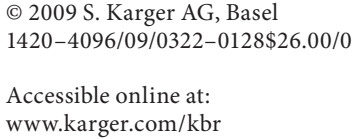

Prof. Xiaoshu Cheng, $\mathrm{PhD}$, MD

Department of Cardiology, Second Affiliated Hospital, Nanchang University No. 1, Minde Road

Nanchang 330006 (PR China)

Tel./Fax +86 791626 8844, E-Mail xiaoshu.cheng@gmail.com 
Table 1. Characteristics of the individual studies of the CYP11B2 $-344 \mathrm{C} / \mathrm{T}$ polymorphism with hypertension in northern Chinese

\begin{tabular}{|c|c|c|c|c|c|c|c|c|c|c|c|c|c|}
\hline \multirow[t]{2}{*}{ Author } & \multirow[t]{2}{*}{ Year } & \multirow[t]{2}{*}{$\begin{array}{l}\text { PCR } \\
\text { method }\end{array}$} & \multirow[t]{2}{*}{ H-WE } & \multicolumn{3}{|c|}{ Hypertension group } & \multicolumn{3}{|c|}{ Control group } & \multicolumn{2}{|c|}{$\begin{array}{l}\text { Hypertension } \\
\text { group }\end{array}$} & \multicolumn{2}{|c|}{$\begin{array}{l}\text { Control } \\
\text { group }\end{array}$} \\
\hline & & & & $\mathrm{CC}$ & $\mathrm{CT}$ & TT & $\mathrm{CC}$ & CT & $\mathrm{TT}$ & $\mathrm{C}$ & $\mathrm{T}$ & $\mathrm{C}$ & $\mathrm{T}$ \\
\hline Gu et al. [4] & 2004 & PCR-RFLP & NS & 39 & 227 & 237 & 53 & 214 & 236 & 305 & 701 & 320 & 686 \\
\hline Ban et al. [15] & 2007 & PCR-RFLP & NS & 21 & 117 & 193 & 18 & 105 & 150 & 159 & 503 & 141 & 405 \\
\hline Hu et al. [16] & 2007 & PCR-RFLP & NS & 9 & 42 & 45 & 9 & 53 & 37 & 60 & 132 & 71 & 127 \\
\hline Hua et al. [17] & 2006 & PCR-RFLP & NS & 52 & 179 & 114 & 13 & 73 & 70 & 283 & 407 & 99 & 213 \\
\hline Li et al. [18] & 2006 & PCR-RFLP & NS & 51 & 224 & 357 & 29 & 131 & 206 & 326 & 938 & 189 & 543 \\
\hline Sun et al. [19] & 2004 & PCR-RFLP & NS & 15 & 69 & 63 & 10 & 47 & 53 & 99 & 195 & 67 & 153 \\
\hline Sun et al. [20] & 2007 & PCR-RFLP & NS & 23 & 109 & 93 & 13 & 58 & 64 & 155 & 205 & 84 & 186 \\
\hline
\end{tabular}

$\mathrm{H}-\mathrm{WE}=$ Hardy-Weinberg equilibrium; NS = not significant; PCR-RFLP = polymerase chain reaction and restriction fragment length polymorphism.

Meta-analysis is a powerful tool for summarizing results from different studies by producing a single estimate of the major effect with enhanced precision. So far, no meta-analysis has examined the association between the CYP11B2-gene polymorphism and hypertension in different parts of China. We performed such a meta-analysis to study the association of the CYP11B2 $-344 \mathrm{C} / \mathrm{T}$ polymorphism with essential hypertension in different parts of China with the intention of providing more reliable findings on the significance of the association.

\section{Methods}

Identification of Eligible Studies

We searched the Cochrane Library, MEDLINE, EMBASE, the Chinese Biomedicine Database, the China National Knowledge Infrastructure platform, VIP and reference lists of articles without limiting to any specific language. The most recent search was in April 2008. All studies that investigated the association between the aldosterone synthase CYP11B2 $-344 \mathrm{C} / \mathrm{T}$ polymorphism and essential hypertension were considered in the meta-analysis. The following key words and subject terms were searched: aldosterone synthase, CYP11B2, polymorphism, hypertension, essential hypertension, idiopathic hypertension, high blood pressure, China and Chinese. Only data from fully published papers were used.

\section{Data Extraction}

Two investigators extracted standard information from independent studies. From each study, the following information was obtained: first author, journal, year of publication, racial background of the study population, demographics, matching, validity of the genotyping method, and numbers of the cases and controls for each CYP11B2 genotype. Frequencies of alleles were calculated for cases and controls from the corresponding genotype distributions.

\section{Statistical Analysis}

Statistical analysis was performed with Cochrane RevMan software version 4.2 (Cochrane Library, UK), and the results were expressed as an odds ratio (OR) with 95\% CI. Heterogeneity among the included studies was analyzed using the heterogeneity $\mathrm{Q}$ statistic test. If the significant $\mathrm{Q}$ statistic $(\mathrm{p}<0.05)$ indicated heterogeneity across studies, the DerSimonian and Laird method in the random effects model was used for meta-analysis. Otherwise, the Mantel-Haenszel method in the fixed effect model was selected.

The potential for publication bias was examined by a Begg's test (funnel plot method) performed by STATA statistical software version 8.1 (Stata Corporation, College Station, Tex., USA). A $\chi^{2}$ test was used to determine whether the observed frequencies of genotypes coincided with the Hardy-Weinberg equilibrium. $\mathrm{p}<0.05$ was considered statistically significant.

\section{Results}

\section{Studies Included in the Meta-Analysis}

Nineteen studies concerning the aldosterone synthase CYP11B2 -344C/T polymorphism and essential hypertension were finally identified as being appropriate for our purposes. These 19 studies encompassed 7 northern Chinese groups [4, 15-20], 3 northeastern Chinese groups [21-23], 7 southern Chinese groups [24-29] and 2 western Chinese groups [30,31], as described in tables $1-4$. The 2 western Chinese groups [30,31] were non-Han Chinese minorities - the Hani and the Yi in Yunnan province, and the Kazakhs in Xingjiang province. One southern Chinese group [24] included the Han Chinese and the minority Dong in Hunan province. 
Table 2. Characteristics of the individual studies of the CYP11B2 $-344 \mathrm{C} / \mathrm{T}$ polymorphism with hypertension in northeastern Chinese

\begin{tabular}{|c|c|c|c|c|c|c|c|c|c|c|c|c|c|}
\hline \multirow[t]{2}{*}{ Author } & \multirow[t]{2}{*}{ Year } & \multirow[t]{2}{*}{$\begin{array}{l}\text { PCR } \\
\text { method }\end{array}$} & \multirow[t]{2}{*}{ H-WE } & \multicolumn{3}{|c|}{ Hypertension group } & \multicolumn{3}{|c|}{ Control group } & \multicolumn{2}{|c|}{$\begin{array}{l}\text { Hypertension } \\
\text { group }\end{array}$} & \multicolumn{2}{|c|}{$\begin{array}{l}\text { Control } \\
\text { group }\end{array}$} \\
\hline & & & & $\mathrm{CC}$ & CT & TT & $\mathrm{CC}$ & CT & $\mathrm{TT}$ & $\mathrm{C}$ & $\mathrm{T}$ & $\mathrm{C}$ & $\mathrm{T}$ \\
\hline Niu et al. [21] & 2007 & PCR-RFLP & NS & 21 & 84 & 77 & 16 & 84 & 89 & 126 & 238 & 116 & 262 \\
\hline Chen et al. [22] & 2006 & PCR-RFLP & NS & 25 & 151 & 175 & 64 & 270 & 332 & 201 & 501 & 398 & 934 \\
\hline Li et al. [23] & 2003 & PCR-RFLP & NS & 6 & 28 & 67 & 5 & 59 & 58 & 40 & 162 & 69 & 175 \\
\hline
\end{tabular}

$\mathrm{H}-\mathrm{WE}=$ Hardy-Weinberg equilibrium; NS = not significant; PCR-RFLP = polymerase chain reaction and restriction fragment length polymorphism.

Table 3. Characteristics of the individual studies of the CYP11B2 $-344 \mathrm{C} / \mathrm{T}$ polymorphism with hypertension in southern Chinese

\begin{tabular}{|c|c|c|c|c|c|c|c|c|c|c|c|c|c|}
\hline \multirow[t]{2}{*}{ Author } & \multirow[t]{2}{*}{ Year } & \multirow[t]{2}{*}{$\begin{array}{l}\text { PCR } \\
\text { method }\end{array}$} & \multirow[t]{2}{*}{ H-WE } & \multicolumn{3}{|c|}{ Hypertension group } & \multicolumn{3}{|c|}{ Control group } & \multicolumn{2}{|c|}{$\begin{array}{l}\text { Hypertension } \\
\text { group }\end{array}$} & \multicolumn{2}{|c|}{$\begin{array}{l}\text { Control } \\
\text { group }\end{array}$} \\
\hline & & & & $\mathrm{CC}$ & CT & TT & $\mathrm{CC}$ & $\mathrm{CT}$ & $\mathrm{TT}$ & $\mathrm{C}$ & $\mathrm{T}$ & $\mathrm{C}$ & $\mathrm{T}$ \\
\hline Jiang et al. [24] & 2005 & PCR-RFLP & NS (Dong) & 9 & 37 & 43 & 9 & 24 & 52 & 55 & 123 & 42 & 128 \\
\hline Jiang et al. [24] & 2005 & PCR-RFLP & NS (Han) & 3 & 19 & 34 & 9 & 47 & 66 & 25 & 87 & 65 & 179 \\
\hline Yuan and $\mathrm{Ha}$ [25] & 2002 & PCR-RFLP & NS & 11 & 55 & 42 & 9 & 65 & 72 & 77 & 139 & 83 & 209 \\
\hline Wang et al. [26] & 2004 & PCR-RFLP & NS & 7 & 41 & 58 & 4 & 42 & 52 & 55 & 157 & 50 & 146 \\
\hline Hu et al. [27] & 2003 & PCR-RFLP & NS & 7 & 41 & 60 & 4 & 38 & 61 & 55 & 161 & 46 & 160 \\
\hline He et al. [28] & 2007 & PCR-RFLP & NS & 31 & 163 & 204 & 12 & 115 & 176 & 225 & 571 & 139 & 467 \\
\hline Pan et al. [29] & 2003 & PCR-RFLP & NS & 58 & 335 & 407 & 9 & 69 & 111 & 451 & 1,149 & 87 & 291 \\
\hline
\end{tabular}

$\mathrm{H}-\mathrm{WE}=$ Hardy-Weinberg equilibrium; NS = not significant; PCR-RFLP = polymerase chain reaction and restriction fragment length polymorphism.

Table 4. Characteristics of the individual studies of the CYP11B2 -344C/T polymorphism with hypertension in western Chinese

\begin{tabular}{|c|c|c|c|c|c|c|c|c|c|c|c|c|c|}
\hline \multirow[t]{2}{*}{ Author } & \multirow[t]{2}{*}{ Year } & \multirow[t]{2}{*}{$\begin{array}{l}\text { PCR } \\
\text { method }\end{array}$} & \multirow[t]{2}{*}{ H-WE } & \multicolumn{3}{|c|}{ Hypertension group } & \multicolumn{3}{|c|}{ Control group } & \multicolumn{2}{|c|}{$\begin{array}{l}\text { Hypertension } \\
\text { group }\end{array}$} & \multicolumn{2}{|c|}{$\begin{array}{l}\text { Control } \\
\text { group }\end{array}$} \\
\hline & & & & $\mathrm{CC}$ & $\mathrm{CT}$ & TT & $\mathrm{CC}$ & CT & $\mathrm{TT}$ & $\mathrm{C}$ & $\mathrm{T}$ & $\mathrm{C}$ & $\mathrm{T}$ \\
\hline Tang et al. [30] & 2006 & PCR-RFLP & NS & 14 & 105 & 152 & 10 & 78 & 179 & 133 & 409 & 98 & 436 \\
\hline Xu et al. [31] & 2004 & PCR-RFLP & NS & 37 & 94 & 55 & 21 & 102 & 45 & 168 & 204 & 144 & 192 \\
\hline
\end{tabular}

$\mathrm{H}-\mathrm{WE}=$ Hardy-Weinberg equilibrium; NS = not significant; PCR-RFLP = polymerase chain reaction and restriction fragment length polymorphism.

Polymerase chain reaction and restriction fragment length polymorphism was used to identify the aldosterone synthase CYP11B2 genotype in the included studies. A Hardy-Weinberg equilibrium test showed that all genotype and allele frequencies in the controls had the expected proportions.
Association between CYP11B2 -344C/T

Polymorphism and Hypertension

The meta-analysis for the northern Chinese (performed first) found no significant association between the risk of hypertension and the CC/TT genotype or $\mathrm{C} / \mathrm{T}$ allele frequency in a total of 7 studies (fig. 1). 
Review: $\quad$ Association between CYP11B2 polymorphism and hypertension in North China (CC versus CT $+\Pi$ )

Comparison: 01 Hypertension group versus control group

Outcome: 01 Hypertension group versus control group

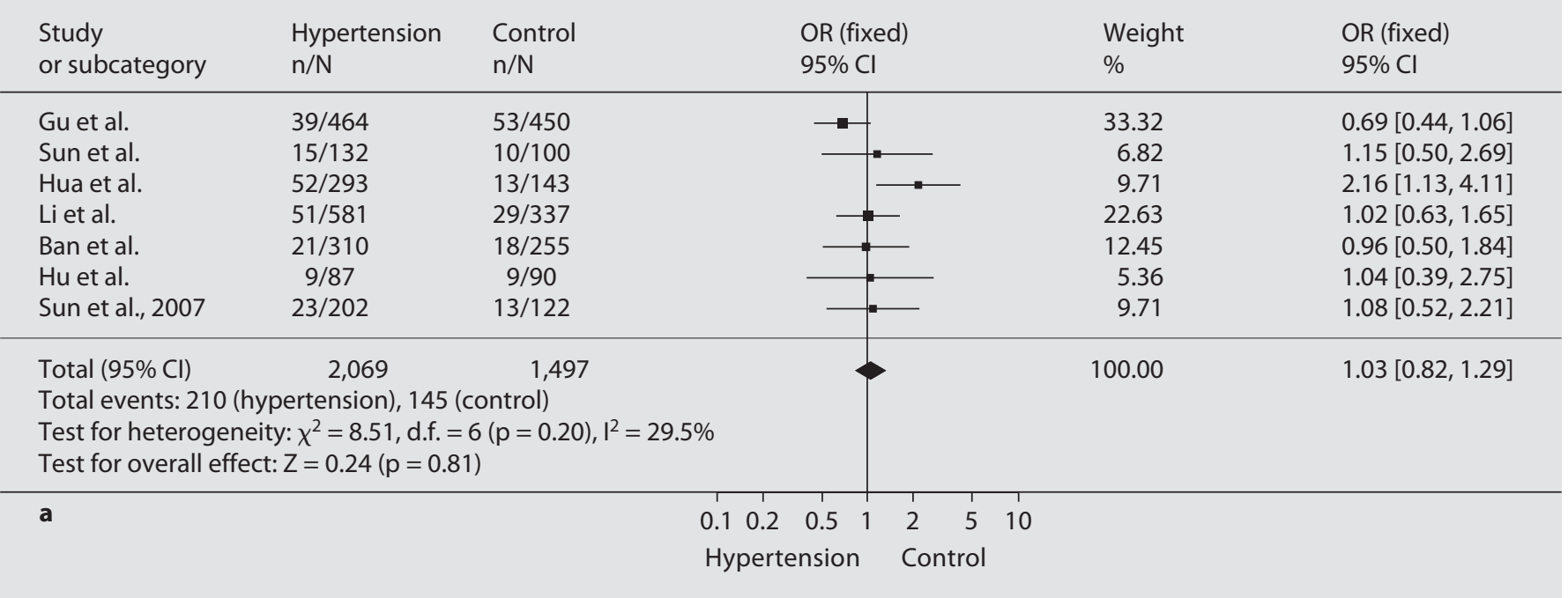

Review: $\quad$ Association between CYP11B2 polymorphism and hypertension in North China (CC versus T allele)

Comparison: 02 Hypertension group versus control group

Outcome: 01 Hypertension group versus control group

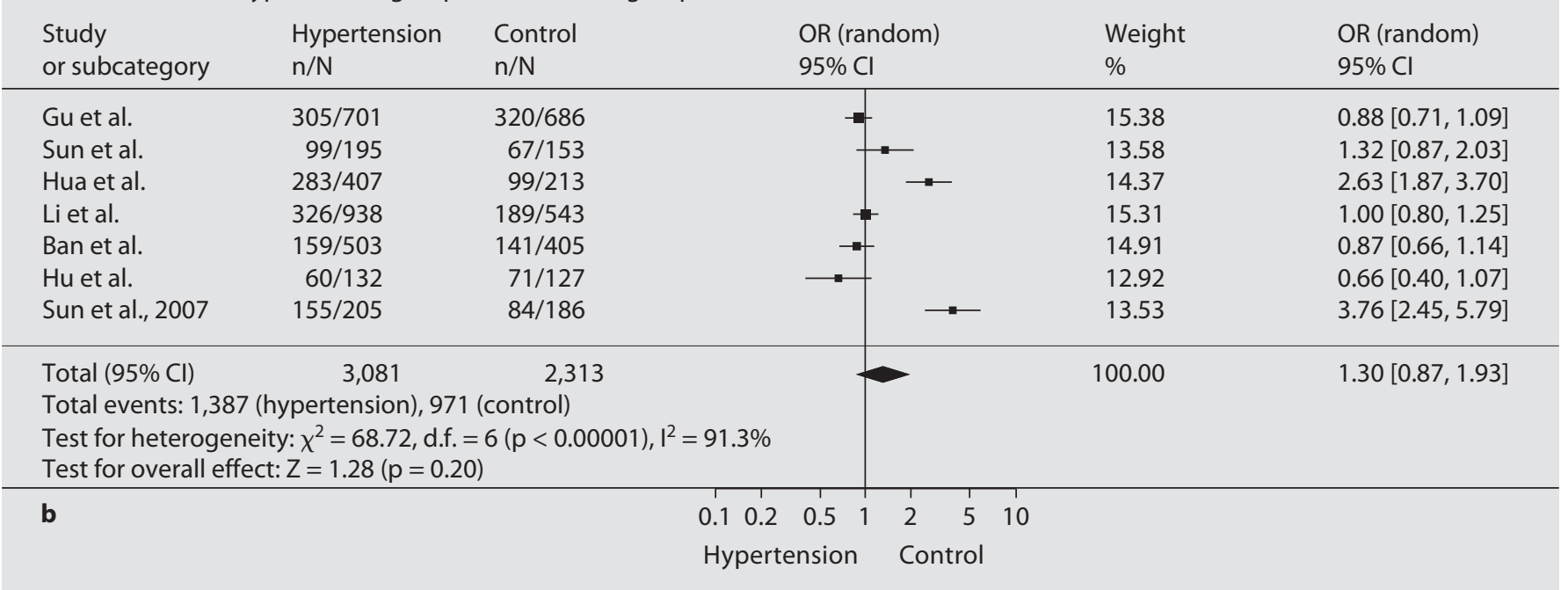

Fig. 1. Association between CYP11B2 polymorphism and hypertension susceptibility in northern Chinese. a Genotype frequency CC vs. CT + TT, Begg's test, $p=0.461$. b C allele frequency vs. C + T, Begg's test, $p=$ 0.20 .

No significant association was observed between the aldosterone synthase CYP11B2 -344C/T polymorphism and hypertension susceptibility in northeastern Chinese. Because both northern and northeastern Chinese all lived north of the Yangtze River, we merged these 2 pop- ulations and analyzed them with a meta-analysis. No significant relationship was found between the CYP11B2 polymorphism and hypertension in this population group (fig. 2). 


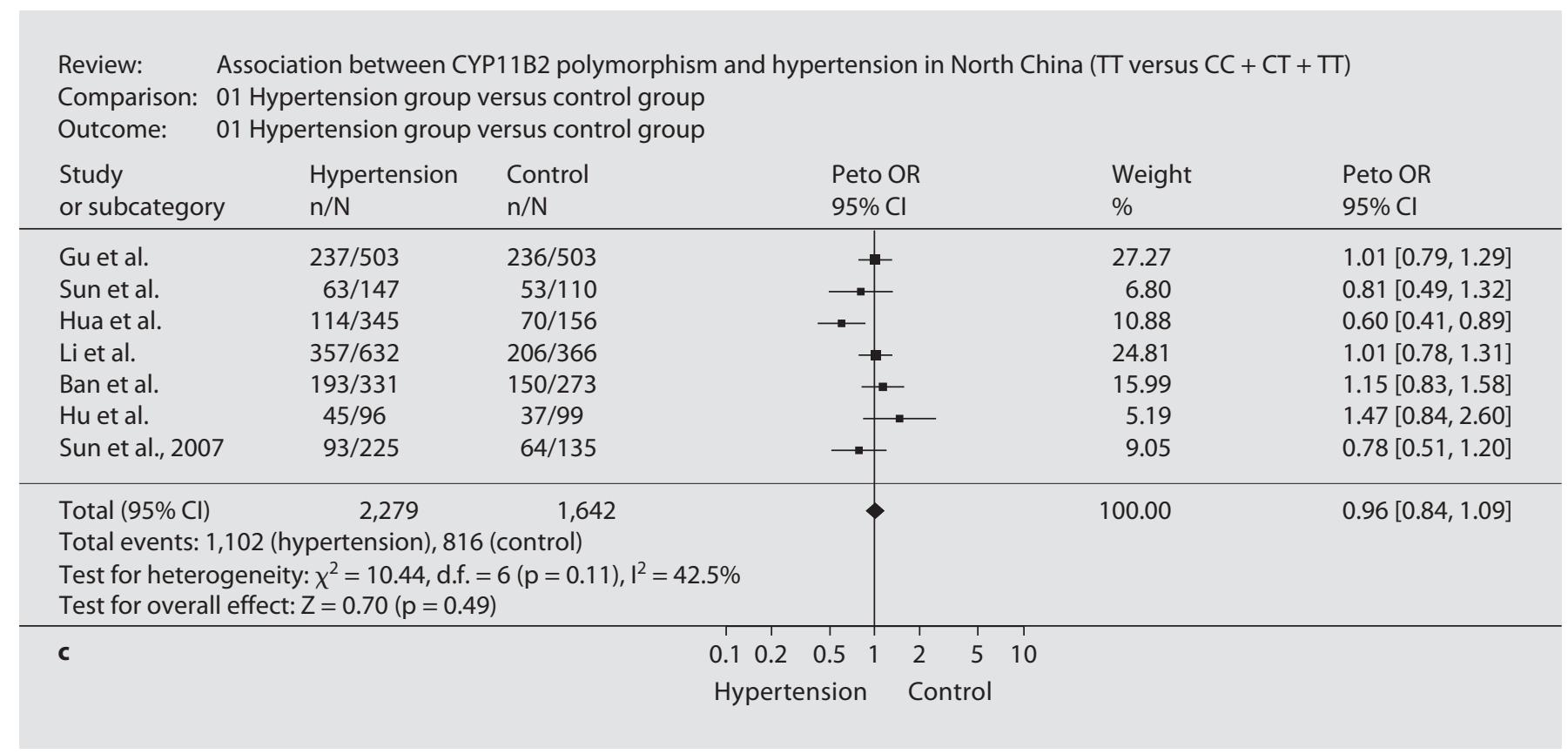

Fig. 1. Association between CYP11B2 polymorphism and hypertension susceptibility in northern Chinese. c Genotype frequency TT vs. CC + CT + TT, Begg's test, $\mathrm{p}=0.219$.

Secondly, we performed a meta-analysis in the southern Chinese. Significant associations between the risk of hypertension and the $\mathrm{CC} / \mathrm{TT}$ genotype and $\mathrm{C} / \mathrm{T}$ allele frequency were found in a total of 7 studies. As illustrated in figure 3, the TT genotype and T allele frequencies in the control group were higher than those from hypertensive populations, without publication bias. Peto's fixed-effect OR estimated for the risk of developing essential hypertension was 0.79 in TT homozygous patients compared with the other genotypes combined (95\% CI 0.67-0.93). Meanwhile, Peto's fixed-effect OR estimated the risk of developing essential hypertension in southern Chinese was 1.27 in C allele patients compared with patients carrying the $\mathrm{T}$ allele (95\% CI 1.111.44).

Thirdly, we performed a meta-analysis for the smallest population included in this study - the western Chinese. Similarly, as no heterogeneity was found across these 2 studies, Peto's fixed-effect model was used to evaluate the associations between the CYP11B2 $-344 \mathrm{C} / \mathrm{T}$ polymorphism and hypertension in the western Chinese. As a result, significant associations between the risk of hypertension and the CC/TT genotype and $\mathrm{C} / \mathrm{T}$ allele frequency were found (fig. 4).
Finally, significant associations between the risk of hypertension and the CC/TT genotype and $\mathrm{C} / \mathrm{T}$ allele frequency were found in a total of 19 studies. As illustrated in figure 5 , the CC genotype and $\mathrm{C}$ allele frequencies in the control group were lower than those from hypertensive populations, without publication bias. Peto's fixed-effect OR estimated the risk of developing essential hypertension was 1.19 in CC homozyous patients compared with the other 2 genotypes (95\% CI 1.02-1.39). Meanwhile, the randomized-effect OR estimated the risk of developing essential hypertension in the whole Chinese population was 1.12 in C allele patients compared with patients carrying the T allele (95\% CI 1.01$1.24)$.

\section{Association of CYP11B2 -344C/T Polymorphism and Hypertension in Different Genders}

Sex hormones such as testosterone and androgens have been shown to have a direct effect on the renin-angiotensin-aldosterone system and on sodium re-absorption in the proximal tubule of the nephron [32]. Therefore, the effects of male sex hormones may decrease sensitivity to the impact of the CYP11B2 polymorphism in males. Conversely, female sex hormones, such as estrogen, may be responsible for increased sensitivity to the 
Review: $\quad$ Association between CYP11B2 polymorphism and hypertension in North and Northeast China (CC versus CT $+\mathrm{TT}$ )

Comparison: 01 Hypertension versus control

Outcome: $\quad 01$ Hypertension versus control

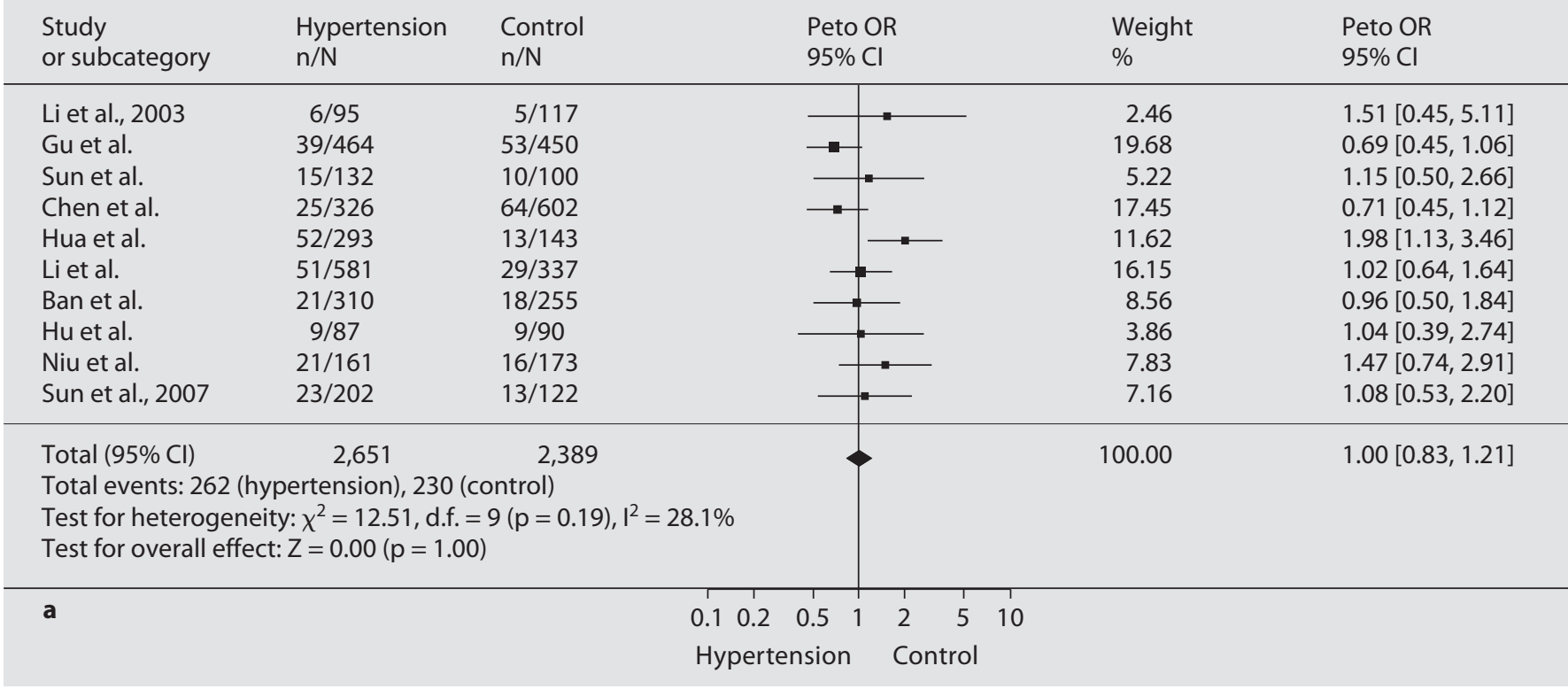

Review: $\quad$ Association between CYP11B2 polymorphism and hypertension in North and Northeast China ( $C$ versus $C+T$ allele)

Comparison: 01 Hypertension versus control

Outcome: 01 Hypertension versus control

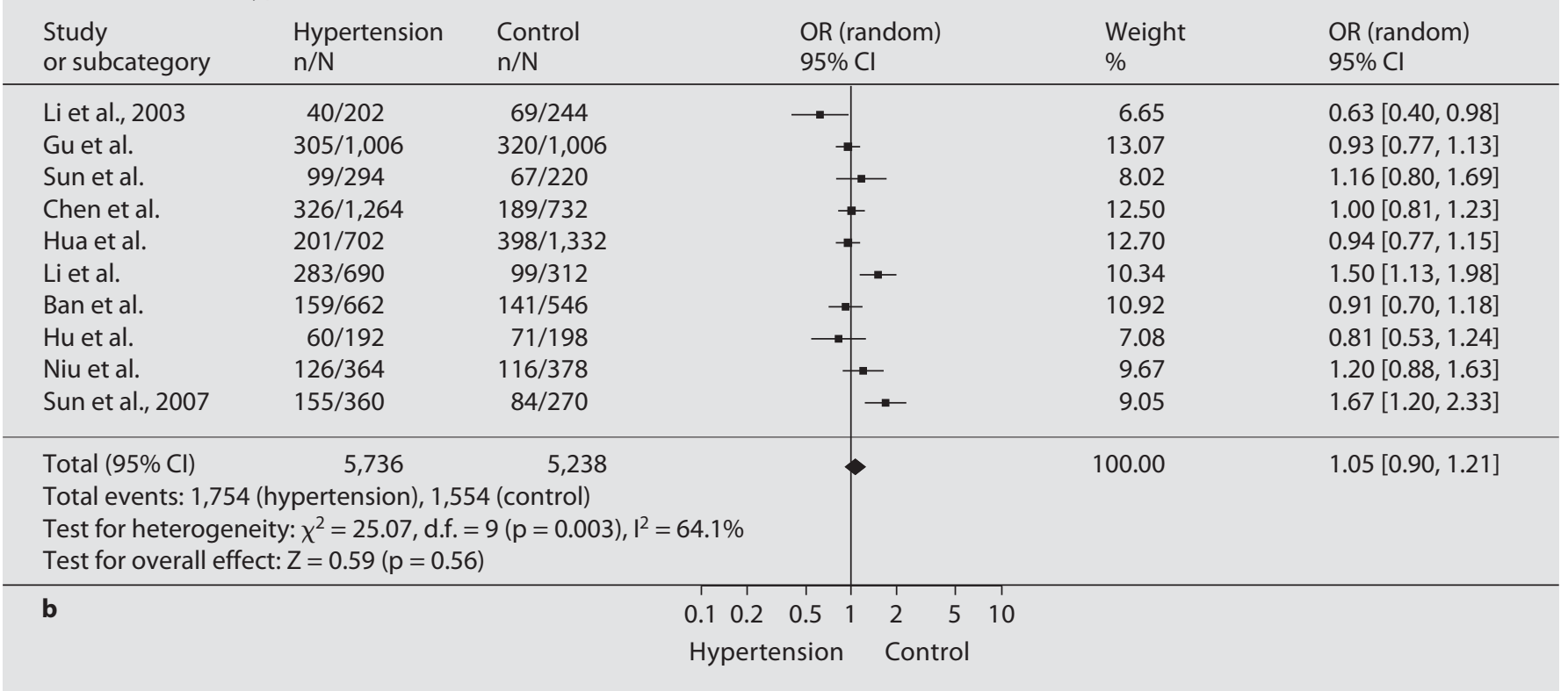

Fig. 2. Association between CYP11B2 polymorphism and hypertension susceptibility in northern and northeastern Chinese. a Genotype frequency CC vs. CT + TT, Begg's test, $\mathrm{p}=0.369$. b C allele frequency vs. C $+\mathrm{T}$, Begg's test, $\mathrm{p}=0.088$. 


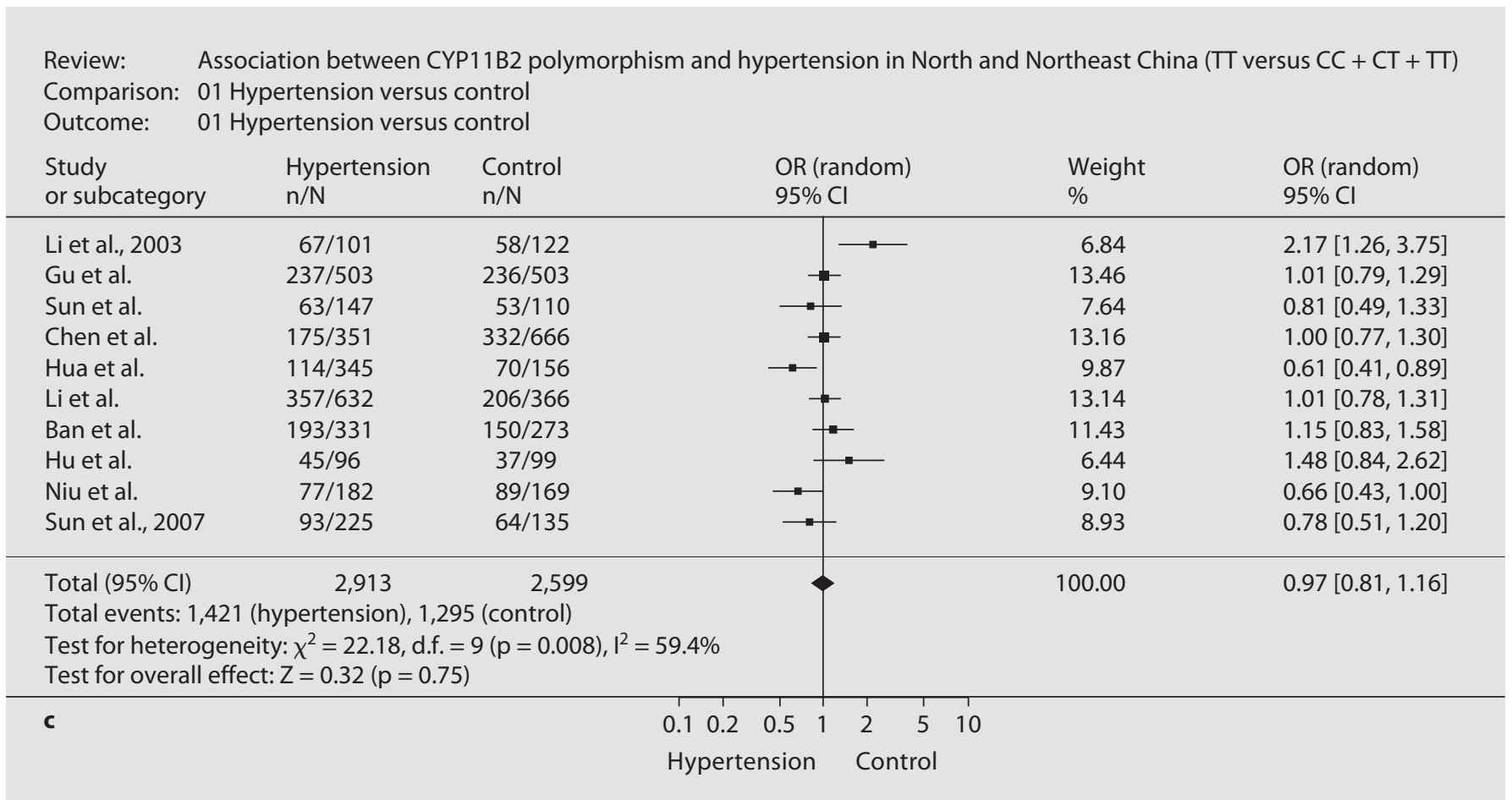

Fig. 2. Association between CYP11B2 polymorphism and hypertension susceptibility in northern and northeastern Chinese. c Genotype frequency TT vs. CC + CT + TT, Begg's test, $\mathrm{p}=0.149$.

CYP11B2 polymorphism in women [33]. Therefore, we identified 3 studies $[4,21,22]$ that demonstrated the relationship between the aldosterone synthase CYP11B2 $-344 \mathrm{C} / \mathrm{T}$ polymorphism and hypertension in different genders, followed by a relevant meta-analysis. No significant association was observed between the aldosterone synthase CYP11B2 -344C/T polymorphism and hypertension susceptibility in either males or females.

\section{CYP11B2 -344C/T Allele Frequency of Normal}

Population in Different Regions of China

Several studies of the Japanese [11, 34], Indians [35], and black and white English people [36], showed no association between the $-344 \mathrm{C} / \mathrm{T}$ allele frequency and hypertension. On the other hand, studies based on other populations from Italy [14] and multi-ethnic populations [2] showed a positive association with hypertension. Seeing that the allele frequency in different regions can be different, we calculated the CYP11B2 -344C/T allele frequencies in the northern, southern and western parts of China. As shown with a $\chi^{2}$ test in table 5 , we found a significant difference between $\mathrm{C}$ allele and $\mathrm{T}$ allele frequencies in different regions of China.

\section{Discussion}

The enzyme aldosterone synthase is the key rate-limiting enzyme in the final step of aldosterone synthesis. Researchers have recently reported that variations of the aldosterone synthase gene (CYP11B2) are associated with essential hypertension and may influence aldosterone secretion [37]. Previous studies suggested that subjects with the SF-1 T allele had a higher urinary aldosterone excretion rate than those with the $\mathrm{C}$ allele, and that the SF-1 T allele was reported to be more common in hypertensive than in normal subjects [8]. The mechanism of the association of hypertensive status with the CYP11B2 polymorphism remains largely unknown. Moreover, studies of different ethnic groups have also shown an inconsistent association between the $-344 \mathrm{C} / \mathrm{T}$ polymorphism and hypertension. One hypothesis to explain this controversy is to presume that the sites of extra-adrenal steroidogenesis are regulated differently [38]. However, no differences were found in H295R human adrenal cells transfected with either the $\mathrm{C}$ or $\mathrm{T}$ allele in the presence of increasing concentrations of SF-1 expression plasmid, in the reported construct activity under basal conditions or after forskolin treatment [39]. 
Review: $\quad$ Association between CYP11B2 polymorphism and hypertension in South China (CC versus CT $+\mathrm{TT}$ )

Comparison: 01 Hypertension versus control

Outcome: $\quad 01$ Hypertension versus control

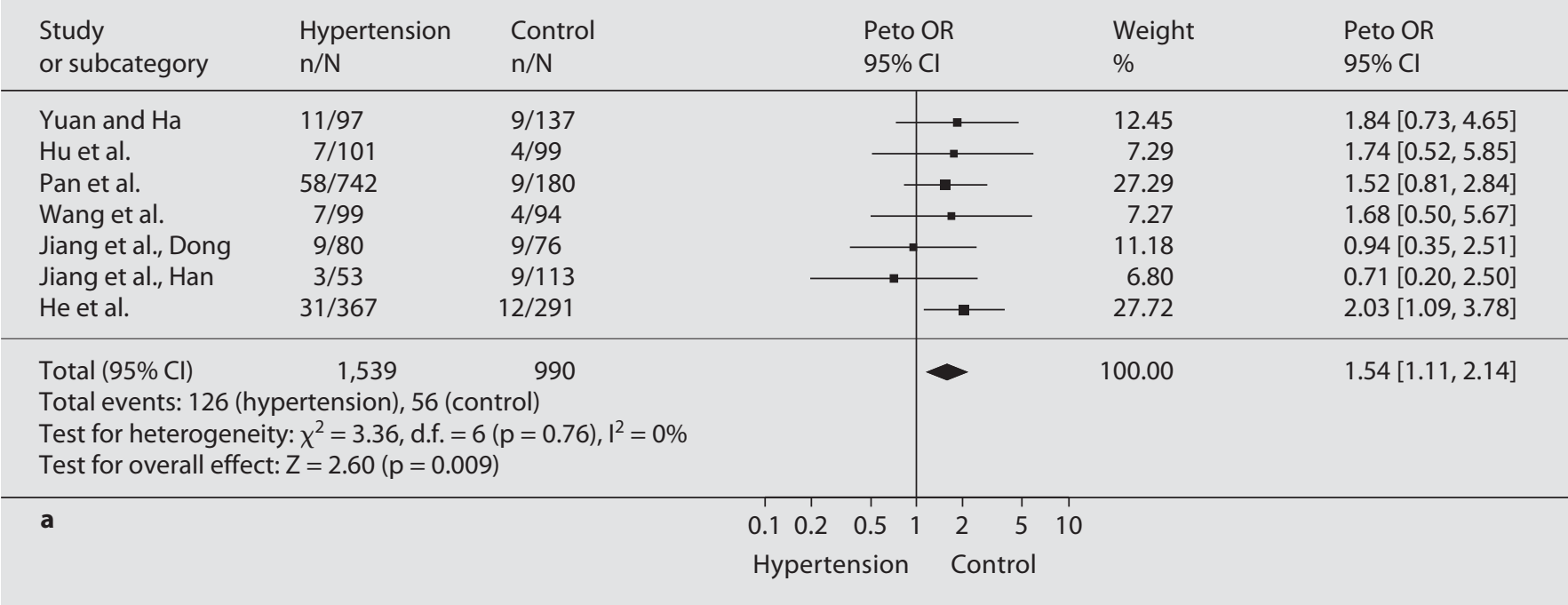

Review: $\quad$ Association between CYP11B2 polymorphism and hypertension in South China (C versus $C+T$ )

Comparison: 01 Hypertension versus control

Outcome: 01 Hypertension versus control

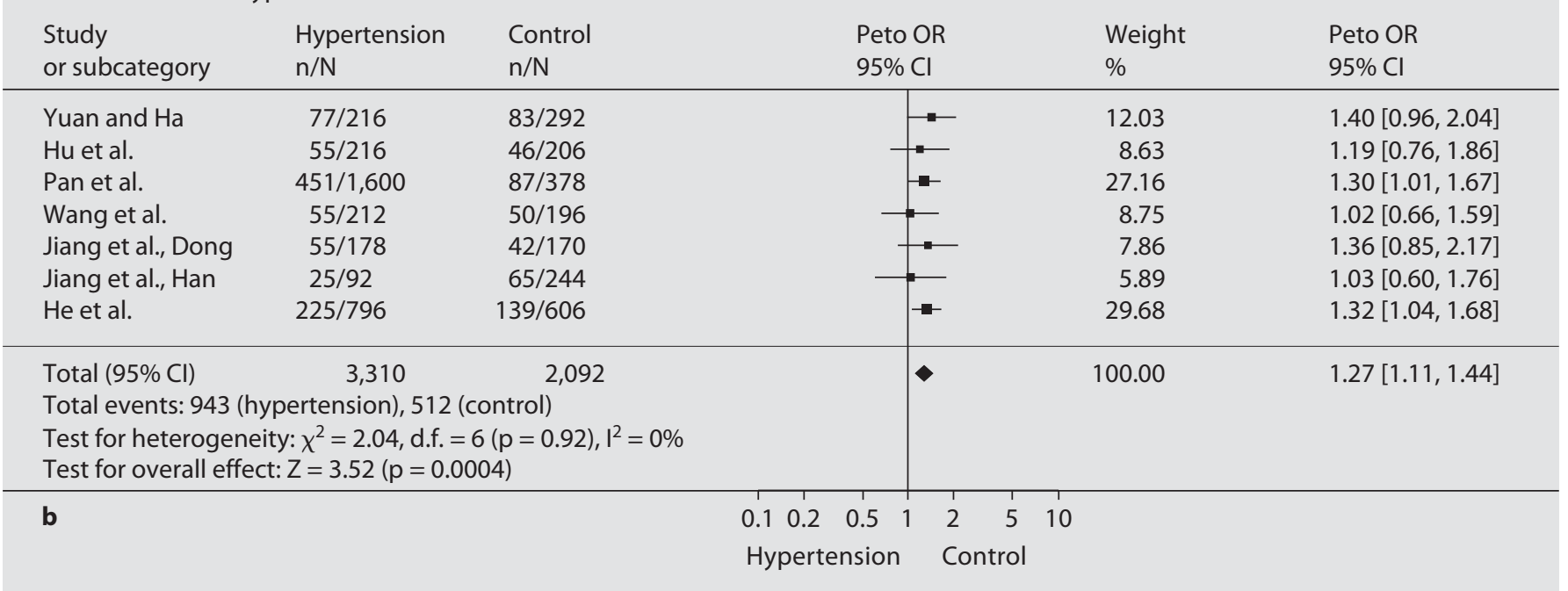

Fig. 3. Association between CYP11B2 polymorphism and hypertension susceptibility in southern Chinese. a Genotype frequency CC vs. CT + TT, Begg's test, $p=0.676 . \mathbf{b} \mathrm{C}$ allele frequency vs. C $+\mathrm{T}$, Begg's test, $\mathrm{p}=$ 0.218 .

This might be due to linkage disequilibrium with other polymorphisms near or within CYP11B2 $[13,40]$, or it might only become functional through epigenetic interaction with other genes [12, 41]. Barr et al. [41] showed that $-344 \mathrm{C} / \mathrm{T}$ was in tight linkage disequilibrium with promoter single-nucleotide polymorphisms in the adjacent CYP11B1 gene, and these may alter the production of cortisol leading to ACTH drive to the adrenal gland, thereby, directly or indirectly, increasing aldosterone production. Another study displayed an increased fre- 


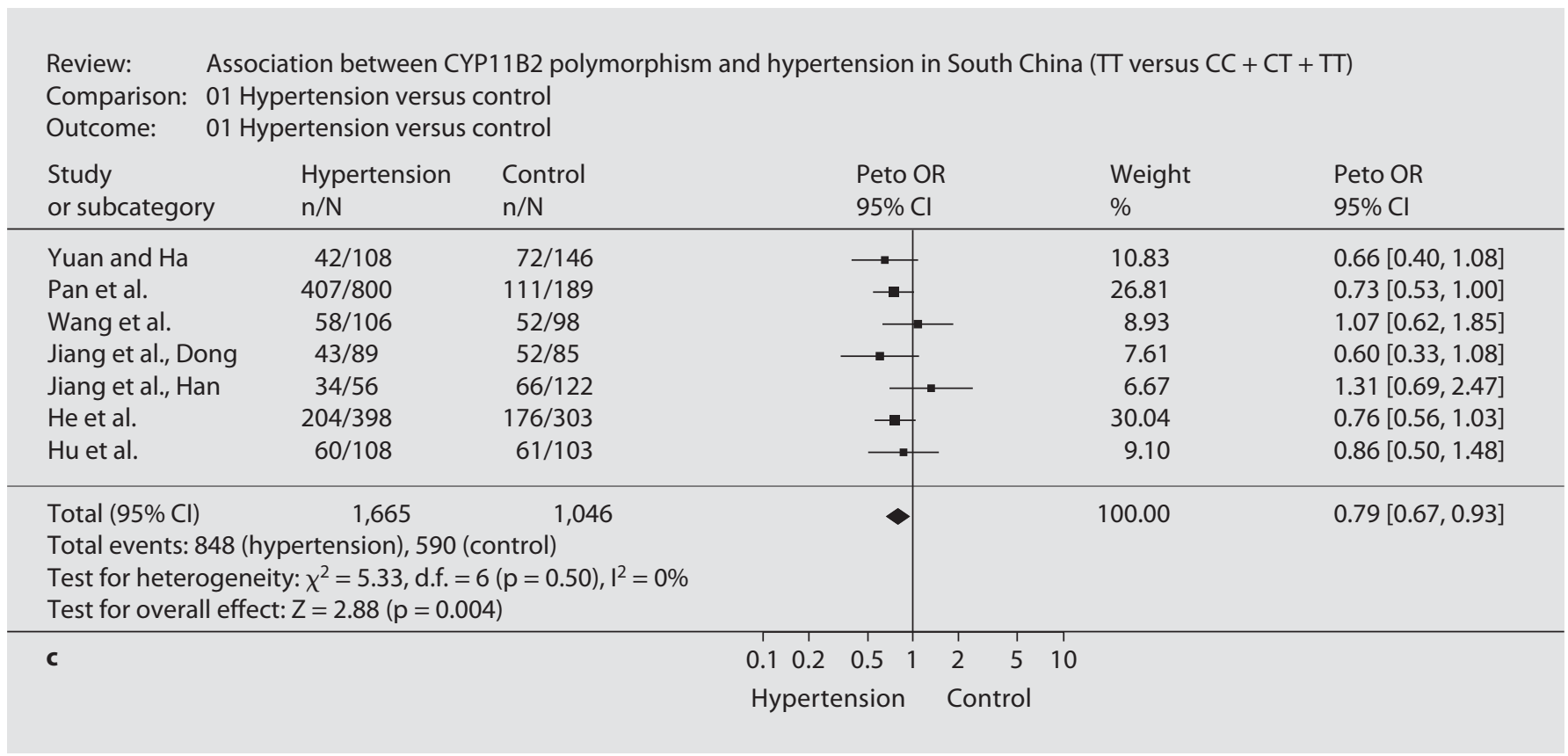

Fig. 3. Association between CYP11B2 polymorphism and hypertension susceptibility in southern Chinese. c Genotype frequency TT vs. CC + CT + TT, Begg's test, $\mathrm{p}=0.302$.

quency of the $-344 \mathrm{TT}$ genotype or the 173Lys allele, which is in linkage disequilibrium with the $-344 \mathrm{~T}$ allele in patients with low-renin hypertension [1]. However, there is also a possibility that other variations in the linkage disequilibrium with these variations confer a substantial risk. Factors such as gender [42], ethnicity [2] and age [43] could be involved in the phenotype expression of this polymorphism.

Our meta-analysis found a significant association between aldosterone synthase CYP11B2 -344C/T risk genotype CC, $\mathrm{C}$ allele and the susceptibility to essential hypertension in Chinese, although no significant association was observed in the northern Chinese.

China, one of the centers of human civilization, comprises the largest geographical span, the highest number of ethnic groups and the most languages of East Asia, as well as one fifth of the world population. There are 56 identified ethnic groups in China, with the Han being the largest in the world. According to government statistics, 93\% of Chinese belong to the Han ethnic majority, with the other 55 officially recognized minorities accounting for the remaining 7\% [44]. Northern and southern Chinese, whose boundary is acknowledged as being between the Huang He (Yellow River) and the Chang Jiang (Yangtze River), were previously found to be genetically different.
The results from Du et al. [45] and Chu et al. [46] confirmed the genetic differentiation of southern and northern Chinese and showed that they are more or less separated by the Yangtze River. Several studies [46-48] indicated a southern origin of the northern populations and a migratory route from south to north after the initial Palaeolithic peopling of East Asia.

We calculated the CYP11B2 $-344 \mathrm{C} / \mathrm{T}$ allele frequencies in the northern, southern and western parts of China, and found a significant difference between $\mathrm{C}$ allele and $\mathrm{T}$ allele frequencies in different parts of China (table 5). As the table indicates, lower $C$ allele frequencies were found in southern Chinese than in their northern counterparts. This higher TT genotype homozygous frequency in the southern Chinese supports the hypothesis that the northern Chinese are of southern origin.

Another meta-analysis by Sookoian et al. [49], which included African, Caucasian, Japanese and Chinese cohorts, indicated that the $\mathrm{T}$ allele is associated with an increased risk for essential hypertension. The most obvious difference between the study by Sookoian et al. [49] and ours is that the latter included individuals with different ethnicities, especially Africans and Caucasians. Since the $\mathrm{T}$ allele frequency reported in Caucasians is $49 \%$ [10], $78 \%$ in Japanese population [1] and of varying 
Review: $\quad$ Association between CYP11B2 polymorphism and hypertension in West China (CC versus CT $+\mathrm{TT}$ )

Comparison: 01 Hypertension versus control

Outcome: 01 Hypertension versus control

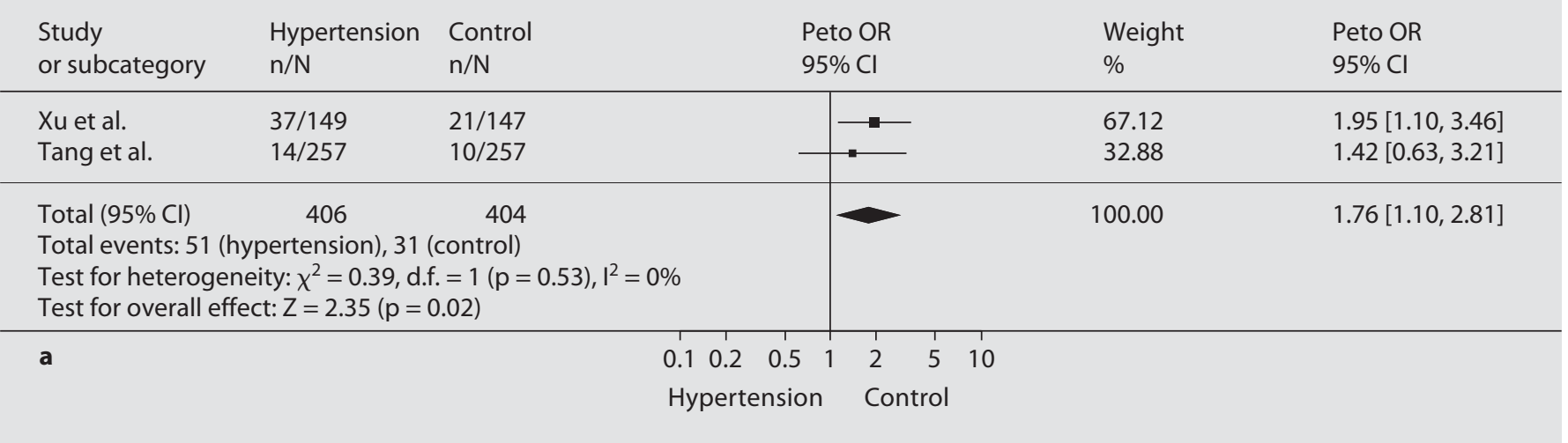

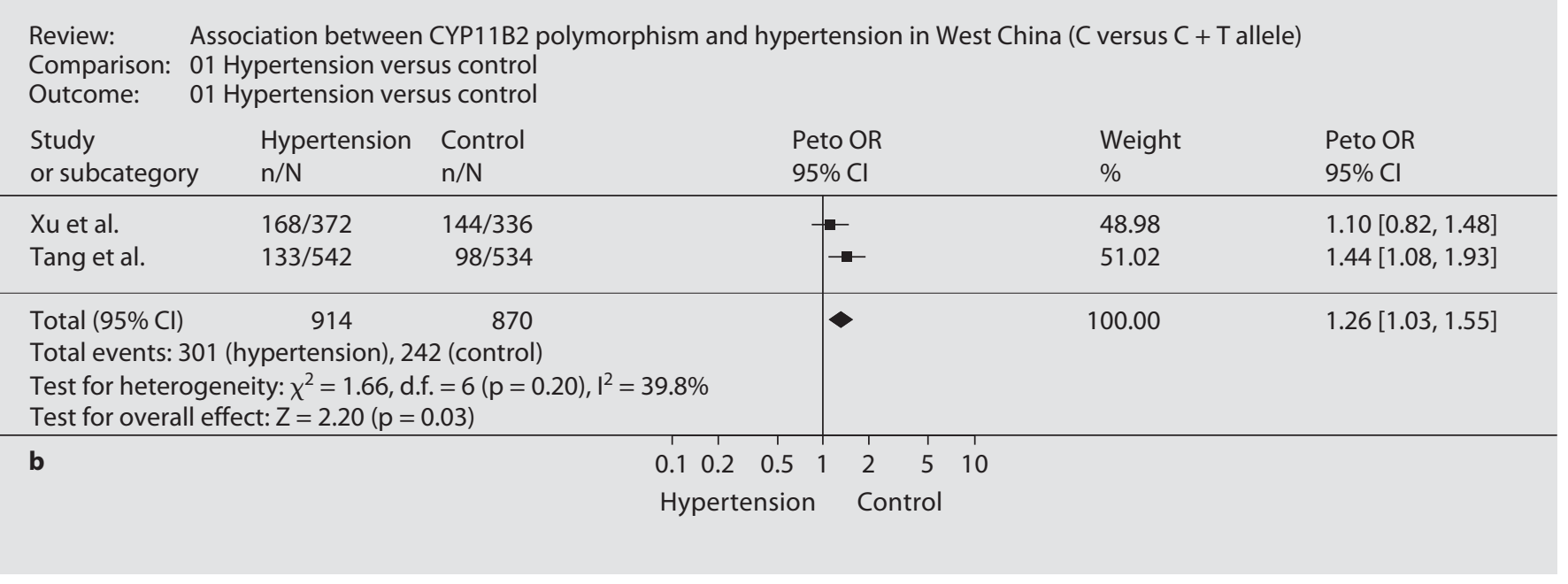

Fig. 4. Association between CYP11B2 polymorphism and hypertension susceptibility in western Chinese. a Genotype frequency CC vs. CT + TT. b C allele frequency vs. C + T.

Table 5. CYP11B2 -344C/T allele frequency of normal in different regions of China

\begin{tabular}{llrl}
\hline Allele & North China & South China & West China \\
\hline $\mathrm{C}$ & $1,554(0.2967)$ & $512(0.2447)$ & $242(0.2782)$ \\
$\mathrm{T}$ & $3,684(0.7033)$ & $1,580(0.7553)$ & $628(0.7218)$ \\
\hline \multicolumn{2}{r}{$\chi^{2}=20.5, \mathrm{p}<0.005}$. & & \\
\hline
\end{tabular}

percentages among the Chinese, it is not surprising that there was a significant difference between the 2 studies.

In this study, we found that there was no statistical discrepancy between the aldosterone synthase CYP11B2
$-344 \mathrm{C} / \mathrm{T}$ polymorphism and hypertension susceptibility in either males or females. In contrast, Gu et al. [4] found an association between the $-344 \mathrm{~T}$ allele and female hypertensive. Because the hypertensive subjects recruited in the study by $\mathrm{Gu}$ et al. were comprised of patients from 


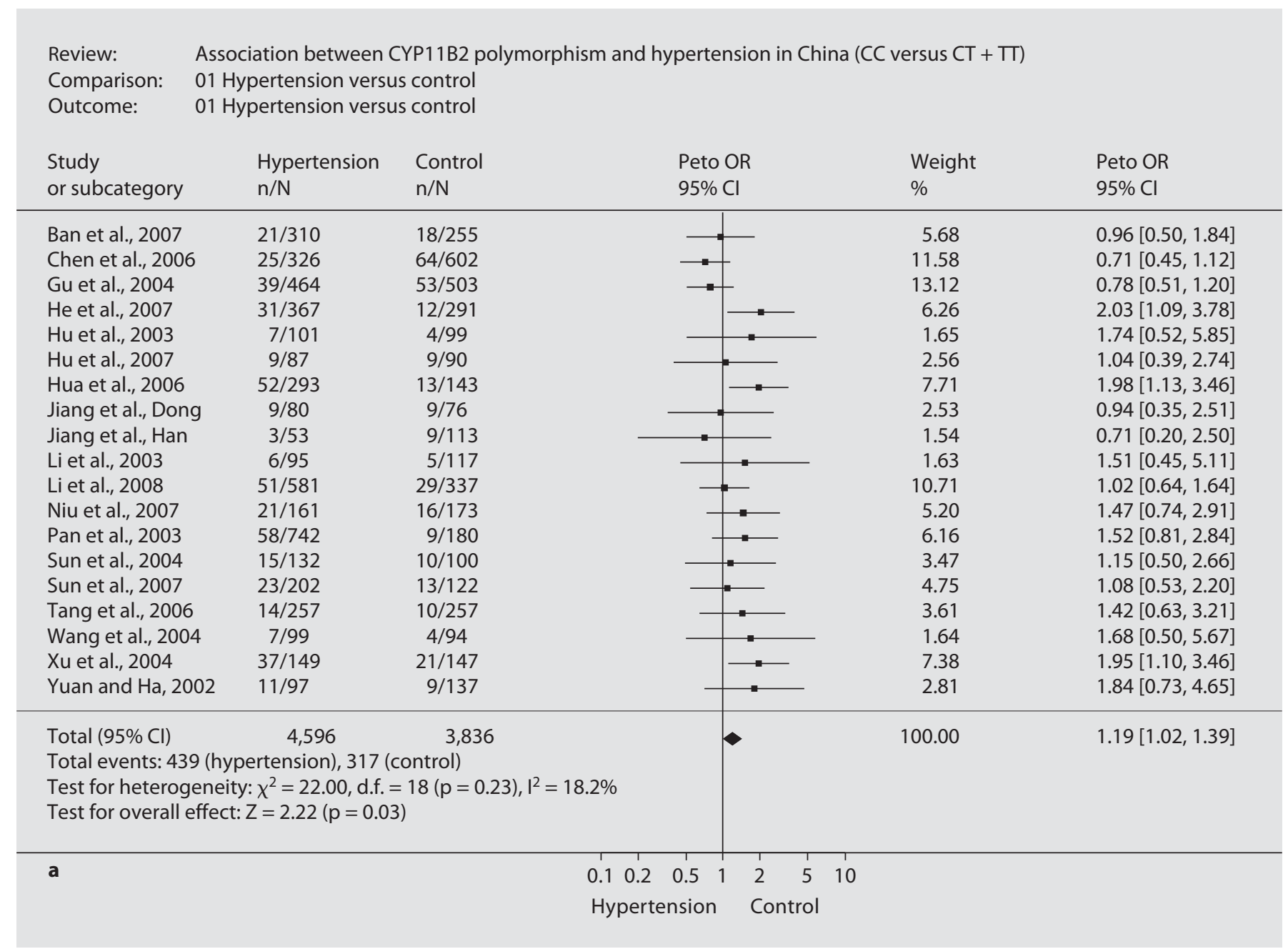

Fig. 5. Association between CYP11B2 polymorphism and hypertension susceptibility in the whole Chinese population. a Genotype frequency CC vs. CT + TT, Begg's test, $\mathrm{p}=0.294$.

northern (Beijing and Shangdong) and northeastern (Jilin) China, while hypertensive patients in Niu et al. [21] (Harbin) and Chen et al. [22] (Dalian) were only from northeastern China, it is not strange that our findings did not match. In addition, a larger sample of hypertension subjects should be analyzed for the $-344 \mathrm{C} / \mathrm{T}$ polymorphism to identify the association between this allele and female hypertension.

There are also several limitations in this study. First, the conclusion that western Chinese have an association with the CC genotype and $\mathrm{C}$ allele frequencies and have a susceptibility to hypertension is based on a relatively small number of participants. Second, because of data limitation, we cannot perform additional analyses in dif- ferent subgroups. Third, due to genetic variants potentially influencing blood pressure or acting through the renin-angiotensin-aldosterone system, dietary salt intake and adiposity should be accounted for.

In brief, the present meta-analysis suggests that the $-344 \mathrm{C}$ allele and CC genotype are associated with susceptibility to hypertension in the Chinese population. It also suggests that different $-344 \mathrm{C} / \mathrm{T}$ allele frequencies are present in different parts of China. 
Review: $\quad$ Association between CYP11B2 polymorphism and hypertension in China (C versus $\mathrm{C}+\mathrm{T}$ allele)

Comparison: 01 Hypertension versus control

Outcome: $\quad 01$ Hypertension versus control

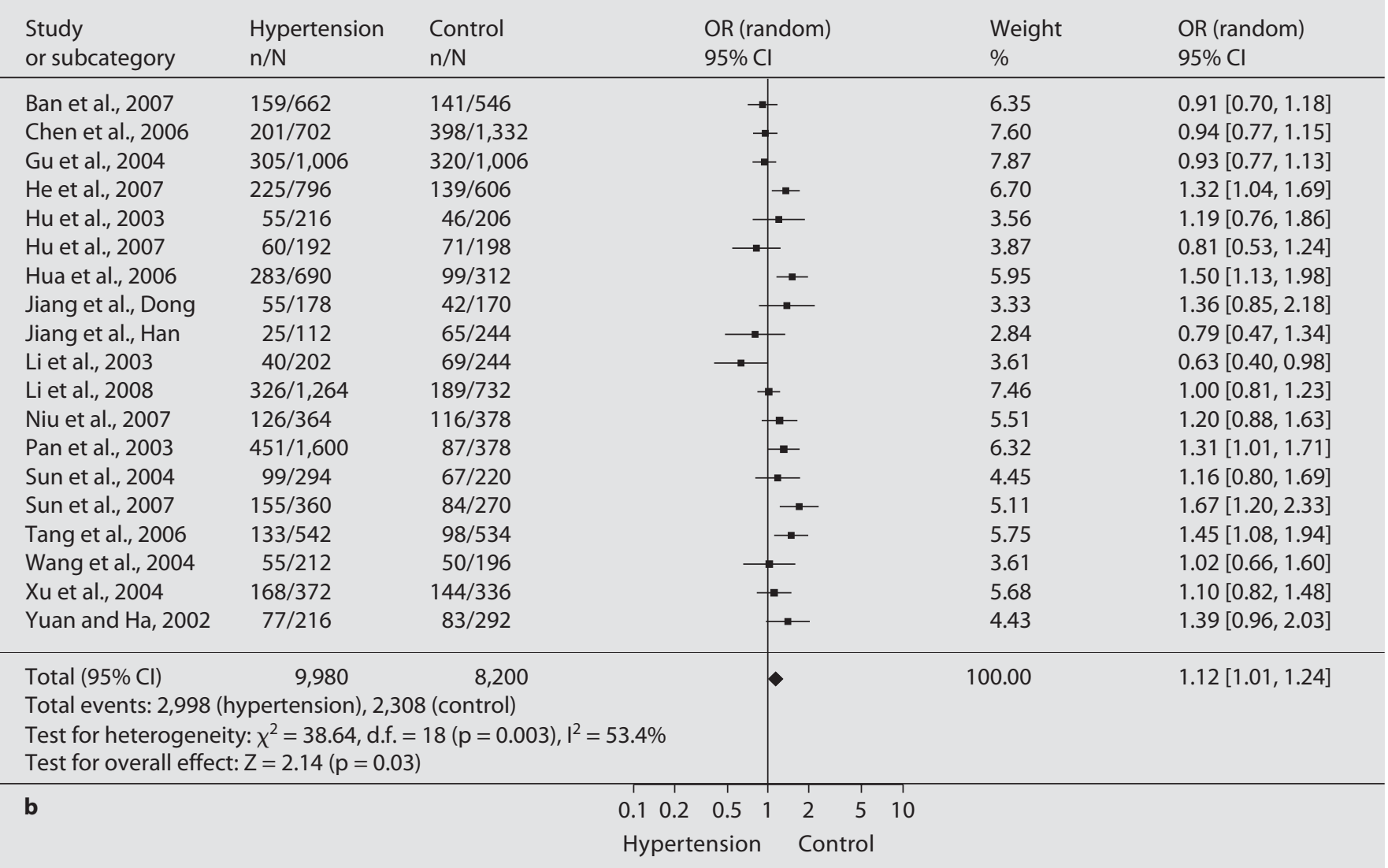

Fig. 5. Association between CYP11B2 polymorphism and hypertension susceptibility in the whole Chinese population. $\mathbf{b} \mathrm{C}$ allele frequency vs. $\mathrm{C}+\mathrm{T}$, Begg's test, $\mathrm{p}=0.056$.

\section{References}

1 Komiya I, Yamada T, Takara M, et al: Lys(173)Arg and -344T/C variants of CYP11B2 in Japanese patients with low-renin hypertension. Hypertension 2000;35: 699-703.

-2 Barbato A, Russo P, Siani A, et al: Aldosterone synthase gene (CYP11B2) C-344T polymorphism, plasma aldosterone, renin activity and blood pressure in a multi-ethnic population. J Hypertens 2004;22:18951901.

3 Xu XJ, Wang SZ, Lin RY, et al: Association of the $\mathrm{T}(-344) \mathrm{C}$ polymorphism of aldosterone synthase gene CYP11B2 with essential hypertension in Xinjiang Kazakh isolated group. Zhonghua Yi Xue Yi Chuan Xue Za Zhi 2004;21:622-624.
$4 \mathrm{Gu} \mathrm{D}, \mathrm{Ge} \mathrm{D}, \mathrm{He}$ J, et al: Haplotypic analyses of the aldosterone synthase gene CYP11B2 associated with stage- 2 hypertesion in northern Han Chinese. Clin Genet 2004;66:409416.

5 Pojoga L, Gautier S, Blanc H, et al: Genetic determination of plasma aldosterone levels in essential hypertension. Am J Hypertens 1998;11:856-860.

6 Russo P, Loguercio M, Lauria F, Barba G, Arnout J, Cappuccio FP, Iacoviello L, Siani A: Age- and gender-dependent association of the $-344 \mathrm{C} / \mathrm{T}$ polymorphism of CYP11B2 with blood pressure in European populations. J Hum Hypertens 2007;21:333-336.
7 Tamaki S, Iwai N, Tsjita Y, Kinoshita M: Genetic polymorphism of CYP11B2 gene and hypertension in Japanese. Hypertension 1999;33:266-270.

$>8$ Davies E, Holloway CD, Ingram MC, Inglis GC, Friel EC, Morrison C: Aldosterone excretion rate and blood pressure in essential hypertension are related to polymorphic differences in the aldosterone synthase gene CYP11B2. Hypertension 1999;33:703-707.

9 Paillard F, Chansel D, Brand E, Benetos A, Thomas F: Genotype-phentype relationships for the renin-angiotensin-aldosterone system in a normal population. Hypertension 1999;34:423-429. 
10 Brand E, Chatelain N, Mulatero P, Fery I, Curnow K, Jeunemaitre X: Structual analysis and evaluation of the aldosterone synthase gene in hypertension. Hypertension 1998;32: 198-204.

11 Tsujita Y, Iwai N, Katsuya T: Lack of association between genetic polymorphism of CYP11B2 and hypertension in Japanese: the Suita Study. Hypertens Res 2001;24:105-109.

-12 Staessen JA, Wang JG, Brand E, Barlassina C, Birkenhager WH, Herrmann SM: Effects of three candidate genes on prevalence and incidence of hypertension in a Caucasian population. J Hypertens 2001;19:1349-1358.

13 White PC, Slutsker L: Haplotype analysis of CYP11B2. Endocr Res 1995;21:437-442.

- 14 Rossi E, Regolisti G, Perazzoli F, Negro A, Davoli S, Nicoli D, Sani C, Casali B: $-344 \mathrm{C} / \mathrm{T}$ polymorphism of CTP11B2 gene in Italian patients with idiopathic low renin hypertension. Am J Hypertens 2001;14:934-941.

15 Ban AR, Yang CC, Li QX, Yu BZ, Wu HY, Liu GZ: The relationship between CYP11B2 polymorphism and essential hypertension. Clin Med Chin 2007;23:304-305.

-16 Hu RL, Zhang CY, Zhao SG, Niu GM, Li HF, Hu RL, Wang ZG, Jiang MF: The correlation between M 235T of angiotensinogen gene, T$344 \mathrm{C}$ of aldosterone synthase (CYP11B2) gene and essential hypertension in Mongolian patients. J Chin Physician 2007;9:31-33.

$\checkmark 17$ Hua Q, Xu W, Li DB, Chen HX, Guo JC, Liu RK, Yang Z: The influence of gene polymorphism of aldosterone synthase gene CYP11B2 (-344T/C) on RAAS in Han nationality essential hypertension patients in Beijing. J Capital Univ Med Sci 2006;27:361364.

-18 Li QX, Gao H, Xu FX, Zhang YQ, Wu HY, Yan HB, Liu GZ: Correlatively between the polymorphism of aldosterone synthase gene, Hind III restriction site on Y-chromosome and essential hypertension (in Chinese). Zhonghua Yi Xue Yi Chuan Xue Za Zhi 2006; 23:294-297.

-19 Sun XJ, Hou XF, Liu SR, Liu WB, Tao ZG, Li JY: Association between CYP11B2 gene $-344 \mathrm{C} / \mathrm{T}$ polymorphism and essential hypertension in the Han nationality in Shangdong province. Zhonghua Yi Xue Yi Chuan Xue Za Zhi 2004;21:502-504.

-20 Sun XJ, Liu SR, Zhang CH, Yuan GH, Chen HY, Hou XF: Association of aldosterone synthase gene $-344 \mathrm{~T} / \mathrm{C}$ polymorphism with early damage in Han nationality with essential hypertension (in Chinese). Zhonghua Yi Xue Yi Chuan Xue Za Zhi 2007;24:153-156.

-21 Niu WQ, Wang JB, Li SJ, Zhou WY, Zhao JB, Qiu CC: Relationship between aldosterone synthase gene CYP11B2 polymorphisms and essential hypertension in a North Chinese Han population (in Chinese). Zhongguo Yi Xue Ke Xue Yuan Xue Bao 2007;29:329335.

22 Chen D, Wang L, Xue Y, Zhu N: Study of the relationship between CYP11B2 C-344T polymorphism and essential hypertension. J Dalian Med Univer 2006;28:446-449.
23 Li QX, Zhang YQ, Qi FY, Liu GZ, Wu HY, Wu SL, Li YL, Qiao DR, Li XQ: Polymorphism of aldosterone synthase gene CYP11B2 in hypertension in China. Chin J Hypertens 2003;11:238-240.

24 Jiang XL, Huang XM, Duan YF, Zhang S, Yao LP, Li XY: Relationship of polymorphism of aldosterone synthase gene with essential hypertension and blood lipids in high risk population of hypertension in Dong nationality group in Huaihua. Chin J Clin Rehabil 2005;9:61-63.

25 Yuan GX, Ha DW: Association between aldosterone synthase gene $-344 \mathrm{C} / \mathrm{T}$ polymorphism and essential hypertension in Chinese population. Chin Circul J 2002;17:118-120.

26 Wang L, Wang JM, Xie YS, Hu XJ: Relationship of aldosterone synthase gene polymorphism with essential hypertension and plasma aldosterone levels. J Clin Med 2004;21: 524-526.

$27 \mathrm{Hu}$ XJ, Wang F, Wang JM, Wang L, Niu P: Association between aldosterone synthase gene polymorphism and primary hypertension in Chinese Han population. J Clin Cardiol 2003; 19:456-458.

28 He FR, He XY, Shen GX, Wang YM: Relationship between metabolic syndrome and CYP11B2 -344T/C gene polymorphisms in hypertensive patients of Wuhan Chinese. Chin J Microcircul 2007;17:26-28.

29 Pan FM, Zhang N, Jiang SQ, Zhang XQ, Zang TH, Xu XP: Polymorphism of CTP11B2 gene and the effect of Benazepril in essential hypertension. Chin J Hypertens 2003;11:555-558.

30 Tang WR, Wu HY, Li SJ, Zhou XH, Cheng BW, Dong YL: Association of the C-344T polymorphism of CYP11B2 gene with essential hypertension in Hani and Yi minorities of China. Clin Chim Acta 2006;364:222225.

31 Xu XJ, Wang SZ, Lin RY, Wang XF: Association of the T(-344)C polymorphism of aldosterone synthase gene CYP11B2 with essential hypertension in Xinjiang Kazach isolated group (in Chinese). Zhonghua Yi Xue Yi Chuan Xue Za Zhi 2004;21:622-624.

32 Reckelhoff JF, Zhang H, Granger JP: Testosterone exacerbates hypertension and reduce pressure-natriuresis in male spontaneously hypertensive rats. Hypertension 1998;31: 435-439.

33 Song J, Narita I, Goto S, et al: Gender specific association of aldosterone synthase gene polymorphism with renal survival in patients with IgA nephropathy. J Med Genet 2003;40:372-376.

34 Yamagishi K, Tanigawa T, Cui R, Tabata M, Ikeda A, Yao M, Shimamoto T, Iso H: Aldosterone synthase gene T-344C polymorphism, sodium and blood pressure in a freeliving population: a community-based study Hypertens Res 2007;30:497-502.

35 Rajput C, Makhijani K, Norboo T: CYP11B2 gene polymorphisms and hypertension in highlanders accustomed to high salt intake. J Hypertens 2005;23:79-86.
36 Zhu H, Sagnella GA, Dong Y: Contrasting associations between aldosterone synthase gene polymorphisms and essential hypertension in blacks and in whites. J Hypertens 2003;21:87-95.

37 Takeda Y, Furukawa K, Inaba S, Miyamori I, Mabuchi H: Genetic analysis of aldosterone synthase in patients with idiopathic hypertensionism. J Clin Endocrinol Metab 1999; 84:1633-1637.

38 Silvestre JS, Robert V, Heymes C, et al: Myocardial production of aldosterone and corticosterone in the rat. J Biol Chem 1998;237: 4883-4891.

39 Bassett MH, Zhang Y, Clyne C, White PC, Rainey WE: Differential regulation of aldosterone synthase and 11beta-hydroxylase transcription by steroidogenic factor-1. J Mol Endocrinol 2002;28:125-135.

40 Mulatero P, Schiavone D, Fallo F, Rabbia F, Pilon C, Chiandussi L: CYP11B2 gene polymorphisms in idiopathic hyperaldosteronism. Hypertension 2000;35:694-698.

-41 Barr M, Mackenzie SM, Friel EC, Holloway CD, Wilkinson DM, Brain NJ: Polymorphic variation in the 11beta-hydroxylase gene associates with reduced 11-hydroxylase efficiency. Hypertension 2007;49:113-119.

42 Kumar NN, Benjafield AV, Lin RC, Wang WY, Stowasser M, Morris BJ: Haplotype analysis of aldosterone synthase gene (CYP11B2) polymorphisms shows association with essential hypertension. J Hypertens 2003;21:1331-1337.

43 Sarzani R, Salvi F, Dessi-Fulgheri P, Catalini R, Mazzara D, Cola G: Aldosterone synthase alleles and cardiovascular phenotype in young adults. J Hum Hypertens 2003; 17: 859-864.

44 Cavalli-Sforza LL: The Chinese human genome diversity project. Proc Natl Acad Sci USA 1998;95:11501-11503.

45 Du RF, Xiao CJ, Cavalli-Sforza LL: Genetic distance between Chinese populations calculated on gene frequencies of 38 loci. Sci China C Life Sci 1997;40:613-621.

46 Chu JY, Huang W, Kuang SQ, Wang JM, Xu JJ, Chu ZT, Yang ZQ, Lin KQ, Li P, Wu M, Geng ZC, Tan CC, Du RF, Jin LJ: Genetic relationship of populations in China. Proc Natl Acad Sci USA 1998;95:11763-11768.

47 Yao YG, Kong QP, Bandelt HJ, Kivisild T, Zhang YP: Phylogeographic differentiation of mitochondrial DNA in Han Chinese. Am J Hum Genet 2002;70:635-651.

48 Su B, Xiao J, Underhill P, Deka R, Zhang W, Akey J, Huang W: Y-chromosome evidence for a northward migration of modern humans into eastern Asia during the last ice age. Am J Hum Genet 1999;65:1718-1724.

49 Sookoian S, Gianotti TF, González CD, Pirola CJ: Association of the C-344T aldosterone synthase gene variant with essential hypertension: a meta-analysis. J Hypertens 2007;25:5-13. 